\title{
A Beligerância Portuguesa no século Xx: \\ Constantes e Motivações \\ Resumo
}

Depois de uma breve panorâmica sobre o que foi a vida internacional durante o século XX, procura identificar-se a posição diplomática de Portugal perante os conflitos militares que mais de perto se cruzaram com a história nacional, nomeadamente, Grande Guerra, Guerra Civil de Espanha, 2. ${ }^{a}$ Guerra Mundial, Guerra Colonial e período posterior à democratização que se seguiu ao Estado Novo e integração na Comunidade Económica Europeia/União Europeia. Deste estudo faz parte a análise das grandes motivações e condicionantes nacionais que levaram às posturas adoptadas perante os conflitos. Concluise que a beligerância — declarada ou camuflada - foi sempre o estatuto nacional adoptado e que ela continuará presente na acção diplomática portuguesa como consequência do exercício nacional de soberania sobre o arquipélago dos Açores. 


\section{A Beligerância Portuguesa no Século Xx: \\ Constantes e Motivações}

Luís Alves de Fraga ${ }^{1}$

\section{Introdução}

Em trabalho anterior ${ }^{2}$ debruçámo-nos sobre a postura portuguesa face aos conflitos militares durante o século XIX e, através dele, chegámos a algumas conclusões que, então, reputámos importantes, pois nos permitiram perceber uma tendência que se definiu na diplomacia nacional ao longo dessa mesma centúria. De facto, e tendo feito o levantamento de todos os conflitos bélicos ocorridos no mundo durante o século XIX, percebemos que Portugal só participou em guerras quando teve o claro apoio da GrãBretanha ou quando estava ameaçada a perda, no todo ou na parte, do património colonial ou, ainda, quando corria perigo a soberania e a independência do território. Em todos os outros casos, a tendência - poderíamos dizer — natural da diplomacia portuguesa foi a de afirmar a neutralidade perante um qualquer conflito armado. Ocorreu uma excepção à "regra" por nós identificada aquando da guerra anglo-boer, pois o Governo cedeu à pressão de Londres, gerando uma situação ambígua: declarar a não neutralidade e a não beligerância, de modo a poder permitir que o território de Moçambique, em especial o porto de Lourenço Marques, servisse de zona de passagem para as tropas britânicas ${ }^{3}$.

Gostaríamos de desenvolver neste breve ensaio uma metodologia semelhante à que utilizámos anteriormente na análise do comportamento político nacional perante os confrontos militares do século XIX. Contudo, face à complexidade das relações internacionais ser-nos-ia impossível, em escassas páginas, levar a cabo o levantamento de todas as situações conflituais que desembocaram em guerras, curtas ou longas, no século XX. E mesmo que o fizéssemos chegaríamos à conclusão de que foram poucas as situações que, de modo directo ou indirecto, obrigaram o Governo português à adopção pública de uma qualquer posição diplomática. Assim sendo, vamos ter de dedicar a nossa atenção somente à análise de cinco situações concretas, a saber: a Grande Guerra (1914-1918), a

\footnotetext{
${ }^{1}$ Universidade Autónoma de Lisboa.

${ }^{2}$ Portugal e os Conflitos do Século XIX: Problemática de uma Neutralidade. In III Colóquio e Dia da História Militar. Actas. Portugal e a Europa - Séc. XVIII a XX. Lisboa: Comissão Portuguesa de História Militar. 1992, p. 219-231.

${ }^{3}$ Fernando Costa - Portugal e a Guerra Anglo-Boer: Política Externa e Opinião Pública (1899 1902). Lisboa: Cosmos, 1998.
} 
Guerra Civil de Espanha (1936-1939), a 2. ${ }^{a}$ Guerra Mundial (1939-1945) ${ }^{4}$, a Guerra Colonial (1961-1974) e, por fim, a pós-integração europeia. Todavia, antes de nos debruçarmos sobre estes conflitos e a posição diplomática nacional perante eles, vamos ter de perceber — segundo a nossa perspectiva - as alterações que ocorreram na política mundial na passagem do século XIX para o século XX e, dentro deste, as que se registaram no decorrer da centúria, porque, umas vezes na periferia outras bem no eixo das mudanças, esteve Portugal de uma forma quase sempre discreta.

\section{Uma centúria de mudanças}

No final do século XIX poder-se-ia dizer que o domínio da política mundial centrava-se na Europa e, dentro desta, a grande decisora dos arbítrios internacionais era a Grã-Bretanha. Os Estados Unidos não tinham ainda ganho estatuto de relevância política a não ser dentro do continente americano onde exerciam forte influência de norte a sul. $\mathrm{Na}$ Europa, tentava disputar o lugar ao Reino Unido a recente unificada Alemanha, cujo motor político e militar era a Prússia. A França, depois de, no início do século XX, ter aplanado os desentendimentos com Londres, buscava, de maneira mais ou menos ínvia, a vingança da humilhante derrota de 1870 imposta pela Prússia. A Rússia começava a despertar para a modernidade e para a grande industrialização. O império austro-húngaro debatia-se para garantir a importância de tempos passados. A traços largos, é este o quadro definidor do começo da centúria de Novecentos, devendo acrescentar-se que os Estados europeus uns mais do que outros - tentavam desbordar importância política, económica e, até, militar impondo, por esse mundo fora, o seu poder sobre territórios coloniais, dominandoos ou protegendo-os ${ }^{5}$.

Ao findar a Grande Guerra e definidos os contornos da paz o quadro anterior havia sofrido mudanças significativas das quais convirá destacar: a Áustria viu reduzida a sua importância como potência regional, a Rússia estava isolada e vivendo uma revolução de novas características que viriam a ser determinantes na evolução futura da história mundial, a França saíra arrasada do conflito, a Grã-Bretanha perdera uma parte do seu prestígio enquanto Estado determinante de equilíbrios, os Estados Unidos mostraram, pela

\footnotetext{
${ }^{4}$ Para os dois grandes conflitos mundiais, optámos pelas designações primitivas: Grande Guerra e 2. ${ }^{a}$ Guerra Mundial.

${ }^{5}$ Ainda continua a ser obra de referência sobre este tema a de J. B. Duroselle - A Europa de 1815 aos Nossos Dias (Vida Política e Relações Internacionais). 3. a ed. S. Paulo: Livraria Pioneira Editora, 1989. Mais recentemente, e com uma visão mais abrangente, pode consultar-se, de Henry Kissinger — Diplomacia. Lisboa: Gradiva, 1996.
} 
primeira vez, que a Europa, para resolver os seus próprios conflitos, carecia da ajuda de além-Atlântico, a Alemanha iniciou, pouco mais de uma década após a derrota, uma recuperação económica e militar espectacular. Afinal, o confronto entre o poder naval (configurado pelos Aliados) e terrestre (materializado pelos Impérios Centrais), que a Grande Guerra colocou em evidência, saiu reforçado para o novo período delimitado pelas duas décadas que mediaram entre as guerras mundiais ${ }^{6}$, pois, uma vez mais, no conflito de 1939-1945, será o poder terrestre a desafiar o poder naval.

Convém também realçar que, do ponto de vista das doutrinas políticas, depois da Grande Guerra - ou ainda durante a mesma, como foi o caso da Rússia — se começaram a definir novos caminhos para o entendimento das relações entre o capital e o trabalho. Relações que, pelo menos do ponto de vista teórico, aplanassem os desentendimentos e as lutas a que o feroz capitalismo do século XIX conduziu o mundo. Assim, em oposição ao demo-liberalismo, para além do socialismo soviético da Rússia, nasceu o fascismo corporativista em Itália, buscando, teoricamente, pelo caminho oposto ao de Moscovo, soluções para a eterna luta desgastante entre os trabalhadores e o patronato ${ }^{7}$. A crise de 1929, nos Estados Unidos, veio também demonstrar que o Estado tinha de abandonar a sua postura neutral diante das relações conflituais para assumir um papel interventivo e corrector da acção do mercado. É, por conseguinte, dentro de um quadro doutrinário que se balança entre a social-democracia do norte da Europa, o socialismo soviético, o fascismo corporativo e o Estado-providência, que surgem e são admitidas as ditaduras, nomeadamente militares, as quais buscam definir a tranquilidade social nos Estados com economias degradadas pela guerra ou pelas suas prolongadas consequências. Foi neste contexto que se implantaram as ditaduras do general Primo de Rivera, em Espanha, e a do general Carmona, em Portugal, tal como o nacional-socialismo na Alemanha. Também foi uma consequência do confronto doutrinário do pós-guerra de 1914-1918 que levou, em 1936, à Guerra Civil de Espanha e à condescendente aceitação da ditadura franquista que se lhe seguiu. O mundo, e particularmente a Europa, procurava respostas novas para velhos problemas determinados pela euforia da economia de mercado. Respostas que, fruto da reacção exigida, acabariam por levar, outra vez, ao confronto bélico e à posterior definição

\footnotetext{
${ }^{6}$ Sobre estes conceitos determinantes para a percepção dinâmica dos conflitos, pelo menos até à eclosão da 2. ${ }^{a}$ Guerra Mundial, veja-se Pedro de Pezarat Correia - Manual de Geopolítica e Geoestratégia. Vol.I. 1. reimp. Coimbra: Quarteto, 2004, p. 153-187.

7 Pode, sobre este conceito e o de nacional-socialismo, consultar-se Jean Touchard (dir.) História das Ideias Políticas. Vol.7. Lisboa: Publicações Europa-América, 1970, p. 108-130.
} 
de diferentes equilíbrios conseguidos na sequência de novos ajustamentos da geografia política mundial e, também, europeia.

O expansionismo germânico e nipónico - o Japão vivia, também, sob a administração de um Governo militar — no final da década de 30 do século XX, associado ao desejo megalómano de Mussolini participar ao lado da grande ditadura europeia, acabou por incendiar o mundo, dando origem ao maior confronto bélico já alguma vez vivido pela humanidade ${ }^{8}$. Foram várias as consequências que dele resultaram, mas destacaremos só algumas por nos parecerem mais próximas do quadro nacional onde desejamos movimentar-nos: nascimento de uma unidade política destinada à busca da solução pacífica dos diferendos internacionais - a Organização das Nações Unidas (ONU) — perda de importância global da Grã-Bretanha e da França, surgindo em seu lugar as designadas super-potências - EUA e URSS — que determinaram a bipolarização da vida internacional; aumento da importância estratégica do Atlântico Norte e do arquipélago dos Açores dentro do contexto euro-americano; ampliação dos conflitos militares, um pouco por todo o lado, nas antigas colónias britânicas, francesas e, mais tarde, como veremos, nas portuguesas; afirmação de uma nova unidade económica e política - Comunidade Económica Europeia (CEE) - construída com alguns Estados europeus a qual foi ganhando maior importância e poder com o rodar dos tempos; dicotomia da política interna dos Estados entre bons e maus conforme opção por um dos modelos doutrinários vigentes: economia de mercado ou economia planificada; aumento sucessivo de importância dos conflitos no Médio Oriente; por fim, fechando um ciclo histórico, implosão da URSS com o desmembramento dos Estados que a compunham e desaparecimento do modelo socialista ensaiado.

Os últimos anos do século XX foram marcados pelo aparecimento de conflitos regionais de baixa intensidade, nos Balcãs, em África, no Médio Oriente, na Ásia e na América, procurando a ONU, a Organização do Tratado do Atlântico Norte (OTAN) ${ }^{9}$ e a União Europeia (UE), em diversas ocasiões e momentos diferentes, em conjunto ou separadamente, intervir como entidades moderadoras ou na busca da defesa dos seus próprios interesses.

\footnotetext{
${ }^{8}$ Veja-se Pierre Thibault - História Universal: O Período das Ditaduras: 1918 - 1947. Vol. 12. Lisboa: Publicações Dom Quixote, 1981.

${ }_{9}^{9}$ Aliança nascida, em 1949, como consequência das fricções políticas entre os EUA e a URSS com ameaça de novo envolvimento militar na Europa.
} 


\section{A posição portuguesa na conjuntura do século $\mathrm{XX}$}

Poder-se-á dizer que a proclamação da República, em Outubro de 1910, foi a resposta ao esgotamento de uma Monarquia já incapaz de mobilizar as elites nacionais e a burguesia urbana para enfrentar novos projectos políticos de reforma e reestruturação da vida portuguesa. O país estava acomodado a viver à sombra tutelar da Grã-Bretanha, mantendo-se num nível de analfabetismo elevadíssimo e não encontrando em si mesmo motivações para, dentro do regime monárquico, alterar a situação.

O Governo Provisório da República - mais do que qualquer outro -, com a legislação posta em vigor, mostrou como se deveriam orientar os pilares fundamentais das reformas a levar a cabo para buscar a modernização e dinamismo que faltavam. A guerrilha monárquica logo desencadeada fez espoletar os desentendimentos entre republicanos e foi num quadro de conflito instaurado entre adeptos do novo regime e seus opositores que, em Agosto de 1914 - menos de quatro anos após a mudança da Monarquia para a República -, estalou o confronto bélico na Europa. A Grande Guerra que se iniciava era, por um lado, uma consequência do confronto alemão e inglês gerado pelo crescimento económico germânico, por outro, o desejo de vingança da França e as aspirações expansionistas da Rússia nos Balcãs. A Grande Guerra começou por ser um fenómeno europeu que opunha interesses de grandes Estados dispostos a sacrificarem os dos pequenos para encontrarem equilíbrios de forças. Certas elites portuguesas identificaram-se, nos anseios, com as pequenas nações europeias desejosas de se libertarem dos jugos tutelares dos grandes Estados.

\section{Portugal e a Grande Guerra}

É conhecido o pedido que Londres fez a Lisboa, em Agosto de 1914, aquando da definição de posições perante o conflito que, julgava-se, iria ser rapidamente resolvido: não declarar a beligerância nem a neutralidade. Uma tal postura diplomática acautelava, em primeiro lugar, os interesses da Grã-Bretanha e, só depois, a muito custo, os de Portugal, pois deixava o Governo perante uma ambiguidade bem definida e esta não seria favorável aos interesses nacionais na futura e próxima conferência da paz.

Isto mesmo foi compreendido pela ala mais radical dos republicanos: a dos «Democráticos», companheiros de Afonso Costa. Todos os restantes grupos políticos, dos republicanos aos monárquicos, passando pelos católicos, optaram por aceitar e acatar como boa a proposta inglesa; esqueceram, porém, todo o quadro conflitual que definia a situação portuguesa, os riscos que se desenhavam no horizonte e os interesses nacionais 
postergados. Quanto mais se definia que a guerra não iria ser curta, maiores eram os perigos para Portugal, quer por poder estar em jogo a sua independência quer por se virem a perder parcelas dos territórios coloniais. Em consequência, toda a política interna portuguesa passou a girar à volta da beligerância ou da não beligerância nacional. A teia que os «Democráticos» habilidosamente foram tecendo levou Portugal ao conflito, quando, em Março de 1916, a Alemanha entregou, em Lisboa, a declaração de guerra na sequência da execução do pedido britânico de requisição dos navios germânicos resguardados em portos nacionais.

$\mathrm{Na}$ aparência a beligerância portuguesa garantia somente a possibilidade de se manter intacto o império ultramarino, mas por trás do que era visível outros interesses estavam em jogo. Com efeito, no plano externo, para além de se salvaguardar a independência, havia que garantir a plena aceitação do Portugal republicano numa Europa esmagadoramente monárquica, mas, mais subtilmente, havia que tentar fugir à imagem de Estado protegido pela Grã-Bretanha e, para tanto, era necessário que fosse colhida a sensação de paridade de soberanias entre Lisboa e Londres - o Governo intervencionista buscava o respeito internacional na beligerância. No plano interno a intervenção no conflito no teatro de guerra europeu vinha fortalecer a prática de uma democracia musculada com reforço à censura e a regulação, admitia-se, da ordem interna sob a possibilidade de colocar o labéu germanófilo em todo aquele que se manifestasse contra a beligerância. No plano económico, a participação na guerra criava a possibilidade do Governo socorrer-se, sem limites, dos empréstimos britânicos - esperava-se poder pagálos com as compensações devidas pela Alemanha após a derrota desta - e contava-se com o mútuo apoio comercial que se estabelecera entre os aliados para fazer circular para o estrangeiro as mercadorias produzidas no país e de lá receber os produtos básicos que faziam falta internamente ${ }^{10}$.

Da síntese feita pode concluir-se que a beligerância como instrumento da política portuguesa da época foi imperiosa e ditada pela defesa de superiores interesses nacionais com graduações diferentes, é certo, mas todos importantes dentro da conjuntura externa e interna do momento.

2. Portugal e a Guerra Civil de Espanha

\footnotetext{
${ }^{10}$ Sobre a definição da política beligerante portuguesa, o quadro conjuntural e a manobra política e diplomática desenvolvida deve consultar-se, da nossa autoria, O Fim da Ambiguidade: A Estratégia Nacional Portuguesa de 1914 - 1916. Lisboa: Universitária, 2001.
} 
Em Abril de 1931 Afonso XIII, na sequência das eleições municipais e face à esmagadora maioria republicana vitoriosa, abdicou, deixando livre a possibilidade para se proclamar a República em Espanha ${ }^{11}$.

Os últimos anos de Monarquia espanhola tinham sido passados em sucessivos ensaios de governação ditatorial militar ${ }^{12}$ — de 1923 a 1929 com o general Primo de Rivera e, depois, durante quinze meses, com o general Berenguer - e de "concentração".

A República em Espanha não foi um regime pacífico, pois tinha de resolver não só o atraso cultural do país como, também, de corrigir disparidades e distorções tanto sociais como económicas muito graves e acentuadas. A convulsão política que se instalou entre 1931 e 1936 gerou o caldo de cultura para o confronto de três modelos de governação: o anarquista, o comunista e o social-democrático. $\mathrm{O}$ sucessivo desentendimento entre eles abriu a oportunidade ao levantamento militar que tinha como objectivo final a imposição de uma ditadura conservadora ${ }^{13}$. A Guerra Civil, iniciada em Julho de 1936, serviu para deixar que a Europa — e, até o mundo - confrontasse, no território espanhol, de armas na mão, os diferentes ideais doutrinários: de um lado, estava a democracia e as suas variantes anarquista e comunista e, do outro, as ditaduras fascizantes ${ }^{14}$.

Para Portugal, como é evidente, o período de governação republicana em Espanha foi incómodo, pois aqui vivia-se a fase final da chamada "ditadura militar" e começavam a cavar-se os alicerces do Estado Novo, a partir de 1933.

A ditadura portuguesa, sendo consentida pela Grã-Bretanha - como alternativa era preferível ao descalabro dos últimos anos da 1. ${ }^{a}$ República - estava, nessa altura, ideologicamente a meio caminho entre a prática da doutrina social da Igreja e as doutrinas fascizantes importadas de Itália e assumia, no silêncio dos gabinetes, uma posição que não era de clara simpatia pela aliança luso-britânica nem de aceitação dos imperativos políticos de Londres ${ }^{15}$. À política nacional interessava, na vizinha Espanha, um Governo ditatorial, mesmo que isso a aproximasse das potências em oposição à Grã-Bretanha, porque lhe

\footnotetext{
${ }^{11}$ Para maior informação, veja-se, María Teresa Puga — La Vida y la Época de Alfonso XIII. Barcelona: Planeta, 1997.

${ }^{12}$ Consulte-se, de Joaquim Lleixá - Cien Años de Militarismo en España: Funciones Estatales Confiadas al Ejército en la Restauración y el Franquismo. Barcelona: Editorial Anagrama, 1986.

${ }_{13}$ Para uma visão sintética, consulte-se Aline Angoustures - Historia de España en el Siglo XX. Barcelona: Ariel, 1995, p. 108-144.

${ }^{14}$ Veja-se, de Gabriel Jackson, A República Espanhola e a Guerra Civil (1931 - 1939). 2 vols. Lisboa: Europa-América, 1973.

${ }^{15}$ Para confirmar esta posição, veja-se Luiz Pina de Sampayo - Elementos para o Estudo da Aliança Britânica. In Estudos Históricos. Lisboa: Ministério dos Negócios Estrangeiros, 1984, p. 295-320.
} 
garantia estabilidade peninsular e perenidade governativa. Mas esta atitude, embora fosse conhecida de todas as capitais europeias, não podia ser alardeada como um interesse nacional português. Assim, durante uma curta primeira fase da Guerra Civil, o Governo de Lisboa procurou manter uma aparente, mas falsa, equidistância dos elementos em confronto. Contudo, logo que se percebeu de que a vitória ia pender para o lado nacionalista, a máscara caiu e Lisboa, proclamando, em Londres, a sua não intervenção no conflito, tratou de dar apoio de vários tipos aos franquistas ${ }^{16}$, permitindo, até, que se arregimentasse e organizasse uma força militar — «Os Viriatos» — para combater em solo espanhol.

Como se vê, Portugal optou por uma beligerância ambígua camuflada por uma neutralidade também ambígua. Julgamos que o nexo para esta posição passou por, de momento, a independência não correr perigo e não estarem em jogo os interesses coloniais portugueses e, ao mesmo tempo, encontrar-se assegurada a estabilidade política interna. É, aliás, nossa opinião, que foi este último ponto o determinante para o estabelecimento do chamado Pacto Ibérico, entre Salazar e Franco, o qual, em linhas gerais, previa a criação de um espaço geográfico de paz e neutralidade na Península, em caso de guerra no Velho Continente, e a mútua consulta se esse estatuto tivesse de ser alterado ${ }^{17}$. Deve acrescentarse, contudo, que, no final da década de 30 do século passado, havia, em Lisboa, certezas quanto ao facto de qualquer expansionismo militar na Europa não colocar em perigo as colónias portuguesas. A guerra que se avizinhava seria, inicialmente, europeia e desenvolver-se-ia nas áreas habituais, isto é, no centro do continente só se deslocando para as periferias onde existissem recursos estratégicos, caso que não correspondia à Ibéria. $\mathrm{O}$ único perigo para a neutralidade de Portugal advinha-lhe de exercer a soberania sobre os estratégicos arquipélagos dos Açores e de Cabo Verde.

\section{Portugal e a 2. ${ }^{a}$ Guerra Mundial}

Do final da Guerra Civil de Espanha ao começo da 2. ${ }^{a}$ Guerra Mundial decorreram apenas cinco meses. A Alemanha de Hitler desejava o confronto tão segura estava das suas vitórias imediatas. Desta vez, e ao contrário do que aconteceu no início da Grande Guerra, Lisboa nem consultou Londres sobre a posição diplomática a adoptar, nem

1987.

${ }^{16}$ Veja-se, de César Oliveira - Salazar e a Guerra Civil de Espanha. 1. ${ }^{\mathrm{a}}$ ed. Lisboa: O Jornal,

17 Sobre a política diplomática que abrange a Guerra Civil de Espanha e a 2. ${ }^{\text {a }}$ Guerra Mundial devem consultar-se os 15 volumes da obra Dez Anos de Política Externa (1936 - 1947). Lisboa: Ministério dos Negócios Estrangeiros, 1962 - 1992. 
esperou que fosse a diplomacia inglesa a ditar caminhos: declarou, de imediato, e independentemente das obrigações da Aliança, a sua neutralidade perante o conflito ${ }^{18}$. A existência do Pacto Ibérico não deixava dúvidas quanto ao desejo do Governo português. Mas, também, o facto de o país ser governado por uma ditadura abria a porta a proximidades de entendimento político fácil com a Alemanha. E, na verdade, o Governo manifestou, logo de começo, as suas simpatias por Berlim ${ }^{19}$. Podia fazê-lo, porque a segurança dos territórios coloniais não estava em risco e a independência não se encontrava ameaçada, pese embora a forte corrente falangista, em Espanha, que não escondia o desejo de anexação. No entanto, esta eventual ameaça só poderia realizar-se com o apoio declarado e concreto da Alemanha o qual seria difícil de obter dadas as condições económicas em que ficara a Espanha após a vitória franquista. O problema central, para Lisboa, colocava-se num outro aspecto: a garantia de absoluta neutralidade dos arquipélagos dos Açores e de Cabo Verde. Ou, dito de outra maneira, a interdição do uso daqueles arquipélagos por forças dos países Aliados.

Efectivamente, a Alemanha tinha adquirido, para além de uma excelente capacidade de fazer a guerra em terra, uma superioridade naval, apoiada no uso dos submarinos, que punha, sem margem para dúvidas, em risco a liberdade de navegação no mar. Ocorre que, no meio do Atlântico, nas proximidades dos Açores, por falta de raio de acção dos meios aéreos britânicos, a superioridade submarina germânica era absoluta, facto que impunha a militarização das ilhas açorianas para garantir a neutralidade, sendo que esta defesa estava mais virada contra a Grã-Bretanha do que contra a Alemanha pois esta não mostrava interesse na ocupação do arquipélago. No começo do conflito, qualquer facilidade que Lisboa desse aos Ingleses era considerada como um acto beligerante e implicaria, de imediato, a declaração de guerra de Berlim a Portugal. E, acontecendo tal, isso remeteria para um quadro em tudo semelhante ao das invasões francesas, pois a Espanha teria de alinhar ao lado da Alemanha pela grande dependência que dela estava, pela identificação ideológica e pela impossibilidade militar de lhe opor resistência. Era, por conseguinte, imprescindível garantir a neutralidade, isto é, a não militarização aliada dos Açores, mesmo que se concedessem - como se concederam - favores à Alemanha,

18 Para uma visão sintética da diplomacia de guerra seguida pelo Estado Novo, embora condicionada por um certo pendor salazarista, consulte-se Franco Nogueira - O Estado Novo [1933 1934]. Porto: Livraria Civilização Editora, 2000, p. 177-229.

${ }^{19}$ Nem todos os historiadores são concordantes neste aspecto, donde, para obter uma outra visão da neutralidade nacional, pode consultar-se António José Telo - A Neutralidade Portuguesa e o Ouro Nazi. Lisboa: Quetzal, 2000, p. 19-84. 
nomeadamente, vendendo minério de volfrâmio para endurecimento do aço das peças de artilharia.

Logo desde o começo da guerra, e na previsão de para ela serem arrastados, os EUA passaram a admitir, também, nos seus planos de defesa a ocupação dos Açores. Em Portugal nada se sabia sobre estas intenções, contudo, era fácil adivinhá-las, tendo a percepção do desenrolar das operações navais no Atlântico.

Depois da declaração de guerra do Japão aos EUA, em Dezembro de 1941, o cenário complica-se, porque, agora, Washington tinha fortes motivos para desejar ocupar os Açores ${ }^{20}$. Entretanto, em consequência do rápido avanço militar nipónico, forças militares holandesas e australianas ocupam Timor para se oporem a uma possível invasão japonesa da ilha por causa da sua riqueza em petróleo. Lisboa vê gorados os seus planos de neutralidade e reclama junto de Londres com muita veemência. O que não se previa para as ilhas atlânticas tinha acontecido, afinal, na ilha do Pacífico. Portugal marcou muito bem que não tolerava que a neutralidade fosse quebrada unilateralmente e negociou a colocação de mais tropas em Timor com a condição de holandeses e australianos se retirarem. Londres aceitou, mas Tóquio antecipou-se e, sob a alegação de operação defensiva, informou, em Fevereiro de 1942, que determinara a imediata ocupação de Timor, respeitando a neutralidade portuguesa. O Chefe do Governo e ministro dos Negócios Estrangeiros, Oliveira Salazar, protestou, mas moderadamente. Ficou evidente, perante todos os intervenientes, que Portugal, não queria alterar, de maneira nenhuma, o estatuto de neutralidade que afirmara no início da guerra. Convinha-lhe mais manter-se nas boas graças de Berlim para evitar a desestabilização da Península.

Entretanto, a Espanha continuava a ser coagida pela Alemanha para entrar no conflito ao lado das potências do chamado Eixo. Franco fez tais exigências materiais a Hitler que, não sendo realizáveis, impossibilitaram a beligerância. Mas, internamente, o ditador vizinho viu-se pressionado pelos adeptos da Falange - ala mais conservadora do espectro político espanhol - a aceitar as propostas de Hitler e a anexar Portugal. O risco de guerra para Lisboa é premente. Londres insistiu na transferência da sede do Governo para os Açores, permitindo, deste modo, a alteração do estatuto diplomático e facilitando a beligerância com o consequente risco de invasão do território peninsular, já que Madrid optara por fazer um discurso anti-aliado e anti-britânico. Salazar predispõe-se a ceder à sugestão inglesa, mas só quando na Península se verificarem os primeiros sintomas de

\footnotetext{
${ }^{20}$ Quanto à importância estratégica dos Açores ao longo dos tempos, veja-se António José Telo Os Açores e o Controlo do Atlântico. Porto: Asa, 1993.
} 
guerra. Oliveira Salazar jogou, uma vez mais, claramente, com a impossibilidade de a debilitada Espanha suportar um novo estado de guerra no seu território.

Na Primavera de 1943, a Alemanha estava a entrar, do ponto de vista militar, no plano inclinado que a levaria à derrota e ao colapso. Em Lisboa, o ministro dos Negócios Estrangeiros e Chefe do Governo apercebeu-se da iminente reviravolta na condução da guerra e do esforço que os Aliados iriam, cada vez mais, empenhar para acelerar a derrota da Alemanha. Nessa nova fase do conflito os Açores tornar-se-iam fundamentais como posição estratégica para a luta anti-submarina, visto estar nos horizontes militares dos Aliados a preparação para a invasão da França e ser imprescindível a livre utilização do Atlântico. Em Maio, Oliveira Salazar propôs conversações a Londres para cedência de bases militares no arquipélago. $\mathrm{O}$ acto correspondia a uma clara mudança de estatuto e não passava pela necessidade de conservação do regime como julgam alguns historiadores, mas pela manutenção de uma autoridade aparente sobre todas as parcelas do território nacional. Havia a certeza de que a Alemanha não cortaria relações diplomáticas com Portugal, porque já não possuía capacidade bélica para estender as operações militares à Península.

Nos dois anos seguintes a colaboração com os Ingleses foi marcante enquanto se reduziam os apoios à Alemanha. A neutralidade havia sido assegurada, muito embora tivesse passado por fases distintas, sendo que a última constituía uma descarada quebra ao estatuto apregoado. E tanto o foi que o Presidente do Conselho, em discurso posterior ao fim das operações militares, não teve pejo em classificá-lo com a lapidar designação de «neutralidade colaborante» ${ }^{21}$ à qual contrapomos, hoje, o conceito de beligerância condicionada, que lhe fica nos antípodas, mas que, por isso mesmo, se lhe iguala, pois a colaboração dada a Franco, durante a Guerra Civil de Espanha, e a que foi dispensada primeiro aos Alemães e, depois, aos Ingleses, na 2. ${ }^{a}$ Guerra Mundial consubstancia uma beligerância que se não efectiva de armas na mão, mas se concretiza nas facilidades concedidas aos contendores activos. A explicação para se ter adoptado este tipo de postura no decurso do conflito mundial resulta, em nossa opinião, de não correrem perigo de perda ou amputação as colónias portuguesas e de se ter como quase garantida a sobrevivência da independência nacional, dada a debilidade estrutural da Espanha e a falta de meios logísticos fornecidos pela a Alemanha para a tornarem numa ameaça a Portugal.

\section{Portugal e a Guerra Colonial}

${ }^{21}$ Vd. Adriano Moreira - Neutralidade Colaborante. Lisboa: Instituto Superior de Ciências Sociais e Política Ultramarina, 1967. 
Desde a Constituição Política de 1822 até à de 1933 ficou bem claro que o território da nação portuguesa compreendia as parcelas que se situavam não só na Europa como também no resto do mundo ${ }^{22}$. Olhada nesta perspectiva, a Guerra Colonial foi uma guerra de secessão, na medida em que, historicamente, os territórios de além-mar, também chamados províncias ultramarinas já desde o tempo da Monarquia, faziam parte integrante do território do Estado Português. Eram, de facto, colónias, mas de jure integravam o território da nação. Assim, quando em 1961, estalou o conflito armado em Angola, embora fossem legítimas as razões dos movimentos de libertação, para os detentores do Poder político na época tratava-se de uma insubordinação interna alimentada pelo estrangeiro.

Numa lógica histórica, o Estado Novo não compreendia - e nem admitia compreender - as mudanças que se tinham operado no direito colonial na sequência da vitória aliada na 2. ${ }^{a}$ Guerra Mundial. Oliveira Salazar, embora desconfiando do papel director da Grã-Bretanha e tudo fazendo para dele se subtrair, não aceitava que tivesse passado para os EUA a capacidade de intervenção que antes pertencia à Inglaterra. A política mundial começava a ser regida por um Estado que tinha sido uma colónia britânica geograficamente implantado num continente de antigas colónias. Era natural e lógico que apoiasse todos os movimentos de libertação dos territórios ainda coloniais.

A Organização das Nações Unidas (ONU) — nascida sob os auspícios dos EUA - definiu-se como uma entidade defensora da autonomia dos povos coloniais ou sujeitos a protectorado e, nesta medida, alinhou, desde a primeira hora, com os sectores críticos da posição portuguesa a qual se conservava irredutível quanto à existência de Portugal como um Estado uno embora pluri-continental. Assim, estando contra todas as correntes defensoras das autonomias e independências, o Estado Novo recusava as doutrinas hodiernas e mantinha-se apegado aos conceitos que haviam determinado, em parte, a beligerância na Grande Guerra e a beligerância condicionada na 2. ${ }^{a}$ Guerra Mundial. Quer dizer, a sustentabilidade de um princípio que, pelo menos constitucionalmente, vinha desde 1822, passava por suportar uma guerra no ultramar. Era, afinal, uma guerra "civil" — no plano interno - e uma guerra "contra os ventos da história" - no plano externo ${ }^{23}$. Inevitavelmente, a situação de beligerância para acabar tinha de passar pelo derrube do

22 Jorge Miranda - As Constituições Portuguesas de 1822 ao Texto Actual da Constituição. Lisboa: Livraria Petrony, 1992. Deve notar-se que a Constituição Política de 1911 é a única que não discrimina esses territórios, limitando-se à fórmula «é o existente à data da proclamação da República» (art. ${ }^{\circ}$ 2..$^{\circ}$.

${ }^{23}$ Sobre este conflito veja-se Aniceto Afonso e Carlos de Matos Gomes - Guerra Colonial. Lisboa: Editorial Notícias, 2000 e, do autor, A Força Aérea na Guerra em África: Angola, Guiné e Moçambique: 1961 - 1974. Lisboa: Prefácio, 2004. 
regime vigente e pela introdução de conceitos políticos e doutrinários que iam ao arrepio da tradição histórica. Essa transmutação só poderia ser levada a cabo pelas forças que faziam a guerra, pois só elas tinham capacidade e legitimidade para negar a beligerância que haviam aceitado e executado durante treze anos de conflito militar. Assim se explica, de forma singela, a acção do Movimento das Forças Armadas (MFA) na madrugada de 25 de Abril de 1974 e nos anos que se seguiram até ao desaparecimento do Conselho da Revolução ${ }^{24}$.

\section{Portugal e o pós-integração europeia}

Depois da assinatura do tratado de adesão à CEE, em 1985, e da queda do muro de Berlim quatro anos mais tarde, Portugal, já outra vez fortemente envolvido com a estrutura militar da OTAN, integrou forças militares internacionais em alguns dos teatros de operações mais em destaque. O primeiro foi na Bósnia-Herzegovina, em 1996, tendo enviado forças terrestres para o Kosovo, para o Iraque, para o Afeganistão e Timor-Leste. Quer dizer, depois de estar redimensionado à área europeia, depois de ter sido aceite num espaço económico e político onde o velho conceito de soberania estatal se encontra diluído e, por conseguinte, a problemática da independência deixa de se colocar com acutilância, Portugal passa a pautar e conduzir a sua política externa pelos padrões da beligerância, ainda que integrando forças militares chamadas de paz.

Não nos interessa, no quadro deste ensaio, discutir a dimensão dos contingentes militares envolvidos nas missões que partem para o estrangeiro; interessa-nos compreender a mudança de comportamento político. Essa, julgamos, está explicada pelo corte com o passado colonial, a garantia de sobrevivência autónoma e independente na Península e a integração em organizações internacionais amplas que caucionam ou podem caucionar a defesa de Portugal. De fora fica uma questão que é permanente na Estratégia Nacional portuguesa: o arquipélago dos Açores. Na verdade, porque está geograficamente no centro do Atlântico, ele serve de placa giratória entre a Europa e a América, não podendo ser desprezado pelos EU que o usam como plataforma de apoio. Este facto obriga a condicionalismos da política externa nacional portuguesa, pois tem de levar em conta o interesse de global de Washington o qual, por vezes, empurrará Portugal para situações de novas ambiguidades face a conflitos onde Lisboa não pretende tomar posição. O exemplo mais flagrante disto mesmo é o dos voos de aeronaves da CIA, transportando prisioneiros,

${ }^{24}$ Ainda que não dando uma explicação que vá no mesmo sentido da nossa, veja-se António Reis - Portugal 20 Anos de Democracia. Lisboa: Círculo de Leitores, 1994. 
presumivelmente terroristas, com possíveis passagens pela base das Lajes, na ilha Terceira. São situações que colocam Portugal no eixo das beligerâncias dos EUA, dando-lhe uma feição beligerante, também.

\section{Conclusão}

Nas páginas anteriores, usando de elevado sintetismo para tratar de um tema complexo, depois de, sobre os acontecimentos do século $\mathrm{XX}$, termos traçado as mais evidentes linhas de mudança, procurámos identificar a posição diplomática portuguesa face aos conflitos bélicos de maior dimensão e importância que afectaram a vida política internacional e, em particular, a nacional.

Da análise efectuada ressaltaram conclusões evidentes e de todos conhecidas e outras mais subtis que, afinal, permitem estabelecer o fio condutor do comportamento político português, em ambiente conflitual, independentemente do regime que detém o Poder. Com efeito, vimos que durante a 1. ${ }^{a}$ República, na mais ampla democracia política, aquando da Grande Guerra, perante um quadro de risco para a manutenção da independência e soberania nacionais, os mais lúcidos e esclarecidos sectores republicanos optaram por uma beligerância declarada em oposição a uma ambígua neutralidade permissiva de actos de guerra. Depois, mais tarde e sob um regime ditatorial, verificámos que, perante a Guerra Civil de Espanha, sem que corressem imediato perigo a independência e a soberania, de novo se optou pela prática de actos beligerantes agora acobertados por uma aparente neutralidade e equidistância das partes em confronto. Durante a 2. ${ }^{a}$ Guerra Mundial, ainda que anunciada a neutralidade, o mesmo regime político, praticou acções declaradamente beligerantes, havendo diminutas probabilidades de risco para a integridade da soberania e independência nacionais; a isso chamou «neutralidade colaborante», optando nós por uma designação que nos parece mais consentânea com a verdade dos factos: beligerância condicionada (condicionada a determinados limites). Como sequela da 2. ${ }^{a}$ Guerra Mundial e do posicionamento doutrinal do Estado Novo, deflagrou, no início da década de 60, a Guerra Colonial. Podia ser tomada como um conflito interno, próximo da guerra civil, não fosse colocar-se-lhe a tónica no auxílio internacional que os movimentos de libertação recebiam. Sem sombra de dúvida foi um acto beligerante assumido - e até, para efeitos de propaganda, reivindicado como uma luta contra o comunismo internacional - que se prolongou no tempo durante treze anos de esforço continuado. Como beligerância definia-se, pois, pela defesa da integridade do território nacional. Foram os militares quem lhe pôs termo, pondo termo ao regime 
ditatorial. Após a integração de Portugal na CEE e da derrocada do bloco de Leste, já sem correrem perigos a integridade territorial e a soberania, o Estado português assumiu-se como beligerante em situações de conflito onde a União Europeia, a OTAN ou a ONU se envolveram, reclamando para essas intervenções o título de operações de paz.

Olhando conclusivamente para o exposto pode dizer-se que o Estado português optou sempre, durante o século XX, pela beligerância ainda que, nalguns casos, disfarçando-a com camuflagens de neutralidade. Esta atitude política nem sempre foi resultado de ameaça sobre a independência ou soberania nacionais, nem sequer como consequência de sustentação do regime; quase sempre ela é o efeito da posse da soberania do arquipélago dos Açores o qual constitui uma região estratégica fundamental para a manobra e defesa de interesses que têm a sua sede na Europa ou nos EUA. Assim, e como conclusão absoluta, pode dizer-se que a beligerância nacional esteve, quase sempre, dependente da defesa da independência nacional e da integridade dos territórios coloniais e está dependente da articulação política com as potências económicas e militares da Europa e da necessidade de defesa longínqua dos EUA como resultado da posse soberana dos Açores.

\section{Bibliografia}

AFONSO, Aniceto Afonso e GOMES, Carlos de Matos - Guerra Colonial. Lisboa: Editorial Notícias, 2000.

ANGOUSTURES, Aline - Historia de España en el Siglo XX. Barcelona: Ariel, 1995.

CORREIA, Pedro de Pezarat - Manual de Geopolítica e Geoestratégia. Vol.I. 1. ${ }^{\text {a }}$ reimp. Coimbra: Quarteto, 2004.

COSTA, Fernando - Portugal e a Guerra Anglo-Boer: Política Externa e Opinião Pública (1899 - 1902). Lisboa: Cosmos, 1998.

DUROSElle, J. B. - A Europa de 1815 aos Nossos Dias (Vida Política e Relações Internacionais). 3. ${ }^{a}$ ed. S. Paulo: Livraria Pioneira Editora, 1989.

FRAGA, Luís Alves de - A Força Aérea na Guerra em África: Angola, Guiné e Moçambique: 1961 - 1974. Lisboa: Prefácio, 2004.

FRAGA, Luís Alves de - O Fim da Ambiguidade: A Estratégia Nacional Portuguesa de 1914 - 1916. Lisboa: Universitária, 2001. 
FRAGA, Luís Alves de - Portugal e os Conflitos do Século XIX: Problemática de uma Neutralidade. In III Colóquio e Dia da História Militar. Actas. Portugal e a EuropaSéc. XVIII a XX. Lisboa: Comissão Portuguesa de História Militar. 1992.

JACKSON, Gabriel - A República Espanhola e a Guerra Civil (1931 - 1939). 2 vols. Lisboa: Europa-América, 1973.

KISSINGER, Henry — Diplomacia. Lisboa: Gradiva, 1996.

LLEIXÁ, Joaquim - Cien Años de Militarismo en España: Funciones Estatales Confiadas al Ejército en la Restauración y el Franquismo. Barcelona: Editorial Anagrama, 1986.

MIRANDA, Jorge - As Constituições Portuguesas de 1822 ao Texto Actual da Constituição. Lisboa: Livraria Petrony, 1992.

MOREIRA, Adriano - Neutralidade Colaborante. Lisboa: Instituto Superior de Ciências Sociais e Política Ultramarina, 1967.

NOGUEIRA, Franco - O Estado Novo [1933 - 1934]. Porto: Livraria Civilização Editora, 2000.

OLIVEIRA, César - Salazar e a Guerra Civil de Espanha. 1. ${ }^{a}$ ed. Lisboa: O Jornal, 1987. PORTUGAL — Dez Anos de Política Externa (1936 - 1947). 15 vols. Lisboa: Ministério dos Negócios Estrangeiros, 1962 - 1992.

PUGA, María Teresa — La Vida y la Época de Alfonso XIII. Barcelona: Planeta, 1997. REIS, António — Portugal 20 Anos de Democracia. Lisboa: Círculo de Leitores, 1994.

SAMPAYO, Luiz Pina de - Elementos para o Estudo da Aliança Britânica. In Estudos Históricos. Lisboa: Ministério dos Negócios Estrangeiros, 1984.

TELO, António José - A Neutralidade Portuguesa e o Ouro Nazi. Lisboa: Quetzal, 2000. TELO, António José — Os Açores e o Controlo do Atlântico. Porto: Asa, 1993.

THIBAULT, Pierre — História Universal: O Período das Ditaduras: 1918 - 1947. Vol. 12. Lisboa: Publicações Dom Quixote, 1981.

TOUCHARD, Jean (dir.) — História das Ideias Políticas. Vol.7. Lisboa: Publicações Europa-América, 1970. 